\title{
On the Origin, Standardization and Transformation of Independent Colleges in China
}

\author{
Erming Liang ${ }^{1, *}$, Xiaofei $\mathrm{Li}^{2}$ and Zhaodi Long ${ }^{3,4}$
}

\author{
${ }^{1}$ School of Education, Jinggangshan University, Jian, Jiangxi 343009, China \\ ${ }^{2}$ Library, Jinggangshan University, Jian, Jiangxi 343009, China \\ ${ }^{3}$ Vocational Normal School, Jiangxi Agricultural University, Nanchang, Jiangxi 330045, China \\ ${ }^{4}$ Jian Haier Hope Primary School, Jian, Jiangxi 343100, China \\ *Corresponding author. Email: liangerming@jgsu.edu.cn
}

\begin{abstract}
This paper studied on the origin, standardization and transformation of independent colleges in China by literature analysis. It is pointed that under the social background of higher education enrollment expansion, independent colleges have emerged nationwide under the banner of helping the popularization of higher education. Due to many problems in the process of development, the education department has standardized independent colleges in many ways, but it is still difficult to meet the expectations of all sectors of society. At the fervent request for all sectors of society, independent colleges finally usher in the fate of transformation. This analysis indicates that independent colleges which is a product of a specific era will come to an end.

Keywords: Independent colleges in China; Origin; Standardization; Transformation
\end{abstract}

\section{THE ORIGIN OF INDEPENDENT COLLEGES IN CHINA}

As early as the late 1980 s to the mid-1990s, some colleges and universities in China operated some "schools-withinschools" akin to independent colleges today with their partners in different charging methods. These "schoolswithin-schools" included Panyu College of Guangdong University of Technology founded in 1988, International Women's College of Tianjin Normal University founded in 1992, Shengda Economic and Trade Management College of Zhengzhou University founded in 1993, Film and Television College in Sichuan Normal University founded in 1996, etc. On the one hand, these "schools-withinschools" can supplement the funds of colleges and universities. On the other hand, they can expand the scale of higher education. So, they have been acquiesced by relevant departments.

In November 1998, Min Tang, chief economist of the Asian Development Bank, and his wife Xiaolei Zuo, Write to the central government of China, proposing doubling the scale of colleges and universities in the next three or four years. Students benefiting from enrollment expansion were required to pay their own tuition fees, so as to stimulate economic progress. [1] In December 1998, the Ministry of Education of China published the action plan for revitalizing education in the 21 st century, which proposed to steadily expand the scale of higher education. [2] In June 1999, the central government of China agreed to expand the enrollment scale of higher education that year, and the enrollment expansion of Chinese colleges and universities began.
The large scale enrollment expansion of colleges and universities had become a fixed trend, but at that time, most colleges and universities and even the national finance were not in a position to bear the cost of large scale enrollment expansion of colleges and universities. The resources need for large scale enrollment expansion of colleges and universities were so huge. How to promote it when the national finance can't afford it? Colleges and universities in Jiangsu province and Zhejiang province, which have traditionally been highly sensitive to policies and have relatively abundant capital, have taken action in advance. In 1998, Chengxian College of Southeast University began to arrange. In 1998, Wenzheng College of Suzhou University began to arrange. In 1999, City College of Zhejiang University was formally established. Facing the task of enrollment expansion of colleges and universities under the background of insufficient financial funds, the Ministry of Education of China had taken a supportive attitude to the independent action of colleges and universities in Jiangsu province and Zhejiang province. The Ministry of education of China first called for the new mechanism of "Government-Owned and ContractorOperated" and "privately run under state ownership" to run schools on various occasions, and then proposed to further change the situation of government arranged education at the third national education work conference held in June 1996. [3] At this time, it was the general tendency that all kinds of higher education institutions which ran with "Government-Owned and Contractor-Operated" and "privately run under state ownership" appeared on a largescale at that time. 


\section{THE STANDARDIZATION OF INDEPENDENT COLLEGES IN CHINA}

\subsection{The Emergence of New Mechanism Secondary Colleges}

After Jiangsu province and Zhejiang province took action, each province encouraged by the Ministry of Education of China responded one after another and organized a large number of "Government-Owned and Contractor-Operated" and "privately run under state ownership" higher education institutions. Most of these institutions were affiliated to the existing public colleges and universities and became XX College (Branch) of XX University (College). In order to differentiate from the secondary colleges which directly belonged to public colleges and universities at that time, most of the documents classified them as "new mechanism secondary colleges". By 2004, there were more than 300 new mechanism secondary colleges in China.

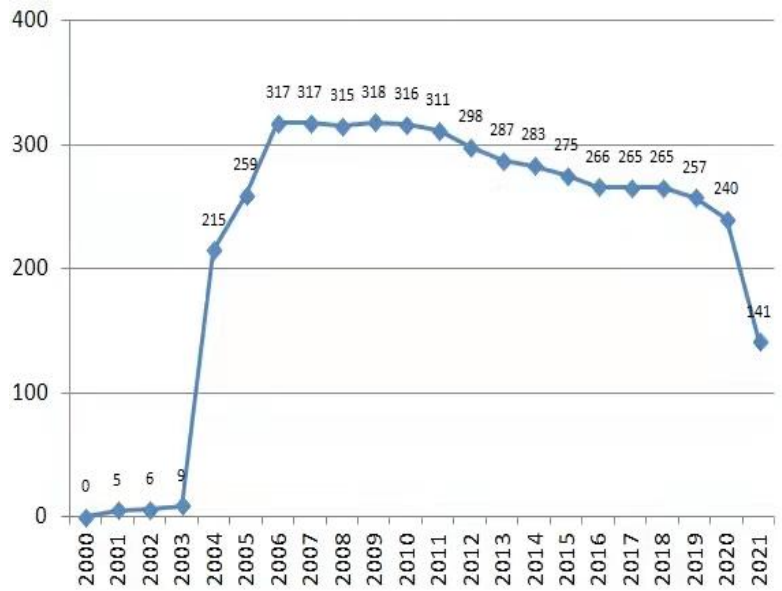

Figure 1. Changes in the number of independent colleges from 2000 to 2021

\subsection{The Problems Brought about by the Development of New Mechanism Secondary Colleges}

The rapid development of new mechanism secondary colleges had brought many problems, including three main ones:

First, various new mechanism secondary colleges were hastily launched, lacking basic school running conditions. Many new mechanism secondary colleges did not even have basic school buildings, teachers and management team, and only rely on sharing the school running resources of the parent colleges and universities.

Second, the school running system of new mechanism secondary colleges was chaotic, and the components of all party involved in running the new mechanism secondary colleges were complex. All parties to the new mechanism secondary colleges regard them as laying golden eggs, which were difficult to straighten out the responsibility and ownership of all parties to the new mechanism secondary colleges. Parent colleges and universities often think that their intangible assets play a key role, while investors think that their invested capital was the king, and there were many contradictions among all parties.

Third, admission score of the students of the new mechanism secondary college was far from those of the students of the parent colleges, but they can obtain the same graduation certificate and degree certificate as the students of the parent colleges when they graduate. Therefore, they were criticized by all sectors of society as "exchanging money for points" and "buying diplomas". In addition, many new mechanism secondary colleges deliberately hid their identity, making it difficult judge their attributes from the name, which was also criticized.

\subsection{Attempt to Solve the Problem Brought about by the Development of New Mechanism Secondary Colleges}

In order to solve these problems, the Ministry of Education of China issued several opinions on standardizing and strengthening the management of independent colleges which conducted by regular colleges and universities with new mechanisms and models in April 2003, [4] which requires:

First, it standardized the name of all new mechanism secondary colleges as independent colleges. Independent colleges were not allowed to use confused names such as $\mathrm{XX}$ campus of $\mathrm{XX}$ University (College), which were collectively referred to as $\mathrm{XX}$ College (Branch) of $\mathrm{XX}$ University (College). Independent colleges issue their own graduation certificates, but the parent university can issue degree certificates to qualified graduates.

Second, it defined the responsibility and ownership of all parties in running the independent colleges, defined the parent university as the applicant and other parties involved in running the independent colleges as the collaborators. It was stipulated that all independent colleges should use the private mechanism, and the funds required for the construction and development of independent colleges and other relevant expenses should be borne by the partners or raised by the private mechanism.

Third, it stipulated independent colleges should have the necessary conditions for running. Generally, it should have the campus including an area of no less than 150 mus. In order to make sure the needs of future development, the development land should be reserved, and the planned campus should cover an area of no less than 300 mus. The construction area of teaching and administrative room should not be less than 40000 square meters. The total value of teaching instruments and equipment should not be less than 10 million yuan, and the number of books should not be less than 40000. An independent college should also have a relatively fixed full-time teacher team with no less 
than 100 people with an employment period of more than one academic year. The proportion of full-time teachers with associate senior titles or above should not be lower than $30 \%$. When an independent college formally enrolls students, all school running conditions should basically meet the standards stipulated by the state.

\subsection{The Problems Encountered by Independent Colleges}

The introduction to the above documents had preliminaries standardized the development of independent colleges. However, as time went on, there were still some problems that cannot be solved, mainly including:

On the one hand, it was difficult for all sectors of society to understand that independent colleges still issue the degree certificates of the parent universities. Some independent colleges even make students obtain the graduation certificate of the parent university through illegal operation. Most people felt that they occupy the resources of the parent universities.

On the other hand, the school running behavior of many applicants and partners of independent colleges was still not standardized. In the process of school running, there were many problems that did not comply with national policies, related party transactions, property rights disputes, etc, Many influential scholars in the field of education even believed that the existence of independent colleges was simply illegal and just a transitional means.

\subsection{Attempt to the Problems Encountered by Independent Colleges}

In order to address these problems, and the era of large scale enrollment expansion of colleges and universities has passed, the Ministry of Education of China issued the measures for the establishment and management of independent colleges in February 2008. [5] The main contents include:

On the one hand, it was stipulated that independent colleges should issue graduation certificates to students who had finished their studies and passed the examination, and the certificates should be stamped with the name of independent colleges. An independent college should, in accordance with the relevant provisions of the state, apply for the qualification to confer a bachelor's degree, and issue a bachelor's degree certificate of an independent college to qualify students.

On the other hand, it further clarified the responsibilities and rights of independent college applicants and partners, as well as the ways and means for both parties to obtain returns. Independent colleges were obliged to further to strengthen their independence. Independent colleges established according to law should register as legal persons in accordance with the relevant provisions of the state, so as to prepare for the separation of independent colleges from their parent universities.

\section{THE TRANSFORMATION OF INDEPENDENT COLLEGES IN CHINA}

\subsection{The Beginning of the Transformation of Independent Colleges}

In 2006, the Ministry of Education of China issued the opinions on the establishment of regular colleges and universities during the Eleventh Five Year Plan period, which proposed that independent colleges can be gradually transformed into independent private regular colleges, and universities in line with the establishment procedures of regular colleges and universities according to needs and conditions.

In September 2008, a large scale transfer of independent colleges appeared for the first time. In this transfer, Deqiang Business College of Harbin University of Commerce was transformed into Harbin Deqiang College of Commerce, Bohai College of Shenyang Normal University was transformed into Liaoning Finance and Trade College, Neusoft Institute of Information of Northeastern University was transformed into Dalian Neusoft University of Information. Amination Institute attached to Jilin Academy of Arts was transformed into Jilin Animation Academy. [6]

The Ministry of Education of China had repeatedly requested the establishment of independent colleges in 2013, 2016 and other time nodes, but the actual effect was quite little. In September 2017, the decision of the Standing Committee of the National People's Congress to amend the law on the promotion of private education was officially implemented, [7] and the urgency of the Ministry of Education of China to promote the transfer of independent colleges was significantly improved. The notice of the general office of the Ministry of education on the establishment of colleges and universities in 2018 clearly stipulates that the application of independent colleges was not limited by the annual application plan. [8]

\subsection{The Approaches to the Transformation of Independent Colleges}

After the general office of the Ministry of Education of China issued the implementation plan for accelerating the transformation of independent colleges in May 2020, [9] all independent colleges are required to formulate the transformation plan by the end of 2020, and the transformation of independent colleges is inevitable. There are three main ways for independent colleges:

First, independent colleges can convert to private colleges. If an independent college has perfect school running agreement, clear division of rights and obligations among school running subjects, and its running conditions meeting the setting standards of undergraduate colleges and universities, it can be transformed into a regular private college. 
Second, independent colleges can turn to public colleges. If an independent college has no social sponsor, it means that it is held separately by public colleges and universities, in cooperation with school foundations, school run enterprises, school affiliated hospitals, alumni associations or school trade unions, and in cooperation with local governments, or the social sponsor intends to withdraw from the holding, and the local government is qualified to undertake the holding, the Ministry of Education of China encourage it transform to an independent public colleges.

Third, independent colleges can stop running. If an independent college's enrollment has been stopped, or its transfer cannot be completed due to various reasons, or the sponsor voluntarily puts forward to stop running the school and meets the conditions, the independent college shall be terminated and the organizational system shall be revoked.

\subsection{The Difficulties in the Transformation of Independent Colleges}

In practice, the transformation of independent colleges has exposed the following problems:

First, although the parent universities of independent colleges that terminate their education mostly recognize the graduates of independent colleges as their alumni, graduates of independent colleges that are in the process of stop running are dissatisfied and feel that they have become orphans after the school was abolished.

Second, some independent colleges have been transformed into vocational and technical universities, which are mistakenly thought by students and their parents to be demoted to junior college or higher vocational colleges, and are unwilling to accept the transformation of independent colleges into vocational and technical universities. As a result, many provincial education departments had to respond one after another and suspend the transformation of independent colleges into vocational and technical universities. Even the Ministry of Education has to specify that vocational and technical universities belong to vocational education in type, which belongs to the same level as ordinary undergraduate universities. Students will obtain undergraduate degrees after graduation. [10]

Third, nearly half of the independent colleges have not been transferred for various reasons and are unwilling to implement the implementation plan for accelerating the transfer of independent colleges issued by the Ministry of Education of China. After the transfer, the "golden signboard" of the parent university will be canceled, and the pressure on enrollment and operation will be different.

\section{CONCLUSION}

As of June 2021, 188 independent colleges across the country have completed the task of transformation, of which 174 independent colleges have been successfully transformed and renamed, 9 independent colleges have been closed and 5 independent colleges are to be closed as announced by the Ministry of Education of China. There are 141 independent colleges in China that have not completed the transfer task, of which 24 independent colleges have entered the proposed transfer stage after being publicized by the provincial or municipal education department, 12 independent colleges have the intention and progress of transfer, and the other 105 independent colleges have no news of transfer.

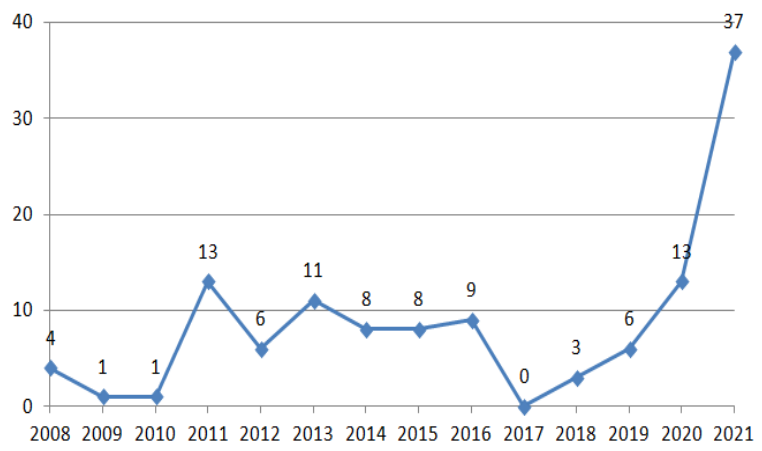

Figure 2. The transformation of independent colleges from 2008 to 2021

Although there are still numerous problems of the transformation of independent colleges, as a transitional product of a specific historical period, independent colleges have completed their historical mission. From the determination of the government, the appeal to the academic community and the reality of the society, the transformation of independent colleges is the general trend.

\section{ACKNOWLEDGMENT}

This research was financially supported by General Issues of the 13th Five-year Plan (2018) for social science of Jiangxi Province "A study on the Historical Changes of the Construction of China's Modern Higher Education System"(Grant NO.18JY20)

\section{REFERENCES}

[1] Y. Zeng, On the Change and Innovation of China's Higher Education System. Shanghai: Fudan University Press, 2015, P. 112.

[2] The Ministry of Education of China, "The action plan for revitalizing education in the 21 st century," in The Bulletin of the State Council of the People's Republic of China, 2nd ed. The General Office of the State Council of the People's Republic of China, Eds. Beijing: The General Office of the State Council of the People's Republic of China, 1999, PP. 37-50. 
[3] The Ministry of Education of the People's Republic of China, Cross Century Chinese Education. Beijing: Higher Education Press, 2002, P. 18.

[4] The Ministry of Education of China, "Several Opinions on Standardizing and Strengthening the Management of Independent Colleges which Conducted by Regular Colleges and Universities with New Mechanisms and Models," in Political newspaper of the Ministry of Education, Z2nd ed. The Ministry of Education of China, Eds. Beijing: The Ministry of Education of China, 2003, PP. 332-334.

[5] The Ministry of Education of China, "the measures for the establishment and management of independent colleges," in The Bulletin of the Ministry of Education of the People's Republic of China, 4th ed. The Ministry of Education of China, Eds. Beijing: The Ministry of Education of China, 2003, PP.3-7.

[6] M. J. Que, “The Transformation of 'Independent College' in China: Distribution, Attribution and Countermeasures," in Research in Education Development, 7th ed., vol. 35. Shanghai Academy of Educational Sciences, Shanghai Society of Higher Education, Eds. Shanghai: Shanghai Academy of Educational Sciences, Shanghai Society of Higher Education, 2015, P. 12.
[7] The Standing Committee of the National People's Congress of the People's Republic of China, "Decision of the Standing Committee of the National People's Congress on Amending the Law of the People's Republic of China on the Promotion of Private Education," in Gazette of the Standing Committee of the National People's Congress of the People's Republic of China, 6rd ed. General Office of the Standing Committee of the National People's Congress, Eds. Beijing: General Office of the Standing Committee of the National People's Congress, 2016, PP. 932-940.

[8] The General Office of Ministry of Education in China, "The Notice of the General Office of the Ministry of Education on the Establishment of Colleges and Universities in 2018," unpublished.

[9] The General Office of Ministry of Education in China, "The Notice of the General Office of the Ministry of Education on the Establishment of Colleges and Universities in 2018," unpublished.

[10] The Ministry of Education in China, "Notes on Issues Related to the Transfer of Independent Colleges," unpublished. 